\title{
Effect of Storage Temperature on the Behaviour of Escherichia coli O157:H7 and Salmonella enterica Serotype Typhimurium on Salad Vegetables
}

\author{
Eleni Likotrafiti ${ }^{1}$, Marios Anagnou ${ }^{1}$, Panagiota Lampiri ${ }^{1} \&$ Jonathan Rhoades $^{1}$ \\ ${ }^{1}$ Department of Food Technology, Laboratory of Food Microbiology, Alexandrian Technological Educational \\ Institute of Thessaloniki, Thessaloniki, Greece \\ Correspondence: Eleni Likotrafiti, Department of Food Technology, Laboratory of Food Microbiology, \\ Alexandrian Technological Educational Institute of Thessaloniki, Thessaloniki, P. O. Box 141, GR-57400, \\ Greece. Tel: 30-231-001-3800. E-mail: likotraf@food.teithe.gr
}

Received: November 22, 2013 Accepted: December 25, 2013 Online Published: January 7, 2014

doi:10.5539/jfr.v3n2p1

URL: http://dx.doi.org/10.5539/jfr.v3n2p1

\begin{abstract}
The behaviour of Escherichia coli O157:H7 and Salmonella Typhimurium on fresh lettuce (Lactuca sativa), cucumber (Cucumis sativus) epidermis and parsley (Petroselinum sativum) under different storage temperatures was studied. Inoculated vegetable pieces were stored at $10{ }^{\circ} \mathrm{C}, 20{ }^{\circ} \mathrm{C}$ and $30{ }^{\circ} \mathrm{C}$ and E. coli $\mathrm{O} 157: \mathrm{H} 7$ and $S$. Typhimurium were enumerated by plate count.

At $10{ }^{\circ} \mathrm{C}$, both $E$. coli $\mathrm{O} 157: \mathrm{H} 7$ and $S$. Typhimurium declined slowly on all three vegetables whereas at higher temperatures the behaviour was markedly different. On parsley and lettuce at $20^{\circ} \mathrm{C} S$. Typhimurium population returned to roughly the starting count at the end of the experiment whereas it increased in cucumber. Growth of up to $0.9 \log \mathrm{cfu} / \mathrm{g}$ was observed on parsley for $E$. coli $\mathrm{O} 157: \mathrm{H} 7$, but population changes on the other vegetables were negligible at $20^{\circ} \mathrm{C}$. At $30^{\circ} \mathrm{C}$ growth was observed on all three vegetables for both E. coli $\mathrm{O} 157: \mathrm{H} 7$ and $S$. Typhimurium.

Growth of E. coli $\mathrm{O} 157: \mathrm{H} 7$ and $S$. Typhimurium increase the risk to the consumer of some types of fresh vegetable. Storage temperature abuse of the above fresh vegetables can lead to food poisoning if not decontaminated appropriately or via cross contamination. This study shows that food safety of fresh produce is improved via storage in chilled temperatures. Even relatively short exposure (a few hours) at higher temperatures can allow growth to occur in all three vegetables thereby increasing the risk to food safety. Chilling fresh vegetables as soon as possible after harvest could prevent growth of pathogens if vegetables are cross-contaminated.
\end{abstract}

Keywords: Escherichia coli, Salmonella Typhimurium, lettuce, cucumber, parsley, storage temperature

\section{Introduction}

Several outbreaks of foodborne illness caused by Salmonella enterica or verocytotoxigenic Escherichia coli (VTEC) in which fresh produce was the suspected vehicle have been reported. Examples of VTEC outbreak vehicles include lettuce (Ackers et al., 1998; Hilborn et al., 1999), fresh spinach (Doyle \& Erickson, 2008) and radish and alfalfa sprouts (Beuchat, 2002). Examples of Salmonella outbreak vehicles include fresh basil (Elviss et al., 2009), bagged leafy salads (Sagoo, Little, Ward, Gillespie, \& Mitchell, 2003), and tomatoes (Doyle \& Erickson, 2008). A recent multistate outbreak of Salmonella Saintpaul in the USA was linked to cucumbers with a total of 81 people being infected and 16 hospitalized (FDA, 2013). According to Olsen, Mackinon, Goulding and Slutskeri, (2000) Salmonella and E. coli O157:H7 were the main pathogens isolated from commodities linked with outbreaks in the USA.

Routes of initial contamination of the vegetables are varied and include undigested manure, contaminated soils, irrigation and washing water, animals, handling during harvesting, postharvest handling or in distribution (Oliveira, Viñas, Anguera, \& Abadias, 2012). Islam et al. (2004 a, b) and Semenov, Van Overbeek and Van Bruggen (2009) reported that E. coli O157:H7 and Salmonella enterica serovar Typhimurium were detected on roots and leaves of lettuce and parsley for 77 and 177 days and for up to 63 days and 231 days respectively in soil contaminated by irrigation water and/or manure compost. 
Storage conditions such as temperature, time, packaging atmosphere and relative humidity are crucial as after processing pathogens can survive and even grow on fresh ready to eat vegetables (Likotrafiti, Smirniotis, Nastou, \& Rhoades, 2013; Tian et al., 2012; Paull, 1999). Sant'Ana, Franco and Schaffner (2012) reported that Salmonella spp. could grow and reach high populations in ready to eat vegetables depending on storage conditions and that definition of effective intervention strategies are needed to control their growth in these products.

A recent study by Liu, Hofstra and Eelco (2013) showed that temperature increase and precipitation pattern changes on contamination sources (manure, soil, surface water, sewage and wildlife) and pathways of foodborne pathogens (focusing on Escherichia coli $\mathrm{O} 157$ and Salmonella spp.) on pre-harvested leafy green vegetables have a close relationship not only with the fate and transport of enteric bacteria, but also with their growth and survival.

The objectives of this work were to investigate the effect of storage temperature on the survival of $E$. coli O157:H7 and Salmonella Typhimurium on lettuce, parsley and cucumber, in order to help establish safer storage conditions from a microbiological perspective. The vegetables used in the study were selected to represent different surface structure and morphology: a broad flat leaf (lettuce), small, more complex leaf structure (parsley) and waxy cuticle (cucumber). The three temperatures of $10^{\circ}, 20^{\circ}$, and $30^{\circ} \mathrm{C}$ were chosen to represent different climatic conditions to which unrefrigerated vegetables are exposed since they may spend long periods in uncontrolled temperature conditions on market stalls, in greengrocers and during transport.

\section{Materials and Methods}

\subsection{Preparation of Vegetables}

Romaine lettuce (Lactuca sativa), cucumber (Cucumis sativus, unwaxed) and flat-leaf parsley (Petroselinum sativum) were purchased from a local greengrocer. Outer or damaged leaves and the core of the lettuce heads were removed and discarded. The inner leaves were cut in circular pieces $(\mathrm{r}=4.5 \mathrm{~cm})$ using a sharp sterile knife and each piece was placed in a sterile plastic Petri dish with the upper (as the lettuce is opened out) leaf surface uppermost. For the cucumber, the skin was removed in strips with a sterile vegetable peeler. These strips were trimmed as required and laid outer side uppermost in a $90 \mathrm{~mm}$ Petri dish so that the whole dish area was covered with a single layer. The surface area of lettuce and cucumber samples was approximately $64 \mathrm{~cm}^{2}$. The parsley leaves were cut with sterilized scissors and placed in Petri dishes in 2 g portions, distributed as evenly as possible with the upper leaf surfaces uppermost. The parsley was measured by mass as it was not possible to calculate the area of the small leaves with complex morphology.

\subsection{Preparation of E. coli O157:H7 and S. Typhimurium inocula}

Rifampicin stock solution was prepared by diluting 1g of rifampicin (Sigma-Aldrich Co., Gillingham, UK) in $20 \mathrm{~mL}$ of dimethylsulphoxide (DMSO, Merck, Darmstadt, Germany). In order to detect and enumerate the E. coli O157:H7 strains throughout the experiment, rifampicin resistance variants were generated. E. coli O157:H7 strains were grown in successive overnight cultures in tryptone soy broth (TSB, Merck, Darmstadt, Germany) containing increasing amounts of rifampicin (from 0.001 to $10 \mu \mathrm{g} / \mathrm{mL}$ ) until growth was observed in the broth with the highest antibiotic concentration. All broths and agar constituents used for enumeration of the resistant variants were supplemented with $10 \mu \mathrm{g} / \mathrm{mL}$ of rifampicin throughout the experiment. E. coli O157:H7 strains NCTC 13126, NCTC 13127, NCTC 13128 and S. enterica serotypes enteritidis PT4, poona 4840 and Typhimurium DT193 were grown for $24 \mathrm{~h}$ at $37^{\circ} \mathrm{C}$ in $10 \mathrm{~mL}$ TSB with $10 \mu \mathrm{g} / \mathrm{mL}$ of rifampicin and without rifampicin respectively. Equal volumes of the three cultures respectively were mixed together and washed three times by centrifuging (3000 rcf, 15 min, Eppendorf, Hamburg, Germany, Centrifuge 5418) with quarter-strength (q-s) Ringer solution (Oxoid, Basingstoke, UK). Cell pellets were resuspended in q-s Ringer solution, with the final concentration being $10^{5}-10^{6} \mathrm{cfu} / \mathrm{mL}$.

\subsection{Inoculation of Vegetables}

A $0.1 \mathrm{~mL}$ aliquot of washed bacterial culture in q-s Ringer solution $\left(10^{5}-10^{6} \mathrm{cfu} / \mathrm{mL}\right)$ was spread over the upper surface of the lettuce and the parsley leaves and the external surface of the cucumber. For lettuce and cucumber, the surfaces were spot-inoculated with 6-8 droplets which were then spread around using the pipette tip in order for the entire surface to be covered as evenly as possible. The cut edges of the pieces were avoided. In the case of parsley, 6-8 leaves were spot-inoculated, using droplets of sizes as close to equal as possible using the pipette tip. The inoculum was allowed $30 \mathrm{~min}$ contact time at room temperature before the samples were transferred to incubators at $10{ }^{\circ} \mathrm{C}, 20{ }^{\circ} \mathrm{C}$ and $30{ }^{\circ} \mathrm{C}$. Samples were analysed periodically over the experimental duration times of $24 \mathrm{~h}, 5$ days, and 7 days at $30^{\circ} \mathrm{C}, 20^{\circ} \mathrm{C}$ and $10{ }^{\circ} \mathrm{C}$ respectively. 


\subsection{Enumeration of E. coli O157:H7 and S. Typhimurium}

Samples were placed in a stomacher bag containing $50 \mathrm{~mL}$ q-s Ringer's solution and homogenized by mixing for $30 \mathrm{~s}$ (normal speed) with a Bag-Mixer 400 stomacher (Seward Ltd., Worthing, UK). For the enumeration of $E$. coli $\mathrm{O} 157: \mathrm{H} 7,0.1 \mathrm{~mL}$ volumes of appropriate serial dilutions of the homogenate were spread on the surface of Sorbitol MacConkey Agar (Lab M, Heywood, UK) supplemented with $10 \mu \mathrm{g} / \mathrm{mL}$ of rifampicin, and the plates were incubated at $37^{\circ} \mathrm{C}$ for $24 \mathrm{~h}$. For the enumeration of $S$. Typhimurium, $1 \mathrm{~mL}$ volumes of appropriate serial dilutions of the homogenate were inoculated in Xylose Lysine Desoxycholate Agar (XLD, Merck, Darmstadt, Germany) using pour plate technique. After the XLD agar plates were set, they were overlaid with a second layer of sterile XLD agar and were incubated at $37{ }^{\circ} \mathrm{C}$ for $48 \mathrm{~h}$. Colony counts were transformed to $\log \mathrm{cfu} / \mathrm{cm}^{2}$ for lettuce and cucumber, and $\log \mathrm{cfu} / \mathrm{g}$ for parsley. Uninoculated samples were also stored under the same conditions and analyzed for the presence E. coli $\mathrm{O} 157: \mathrm{H} 7$ and $S$. Typhimurium.

\subsection{Data analysis}

For each group of experiments, two replicate experiments were conducted, with two samples evaluated per experiment, giving a total of four replicate samples. Microbial counts were transformed to logarithms before computing means and standard deviations; population densities were reported as $\log \mathrm{cfu} / \mathrm{cm}^{2}$ for lettuce and cucumber samples, and as $\log \mathrm{cfu} / \mathrm{g}$ for parsley samples. Although the use of different units prevents direct comparison of absolute counts between parsley and the other vegetables, changes in log count can be compared as these are in effect ratios of populations on the same vegetable. Data from microbiological analyses were evaluated by analysis of variance (ANOVA) using Minitab Statistical Software, Release 15. The level of significance for all tests was 0.05 .

\section{Results}

The change in the populations of the two pathogens on cucumber, lettuce and parsley at 10,20 , and $30{ }^{\circ} \mathrm{C}$ are illustrated in Figures 1 for $S$. Typhimurium and 2 for E. coli O157:H7.

At $10{ }^{\circ} \mathrm{C}, S$. Typhimurium declined slowly on all three vegetables, losing from 0.6 to $1.8 \mathrm{log} \mathrm{cfu} / \mathrm{cm}^{2}$ or $/ \mathrm{g}$ by the end of the experiment at seven days. At higher temperatures the behaviour was markedly different. On parsley and lettuce at $20^{\circ} \mathrm{C}$ initial deviations of up to $0.7 \log \mathrm{cfu} / \mathrm{cm}^{2}$ or $/ \mathrm{g}$ were followed by a return to roughly the starting count. However on cucumber the population increased by $1.8 \log \mathrm{cfu} / \mathrm{cm}^{2}$ within two days, followed by a small decline of $0.6 \log \mathrm{cfu} / \mathrm{cm}^{2}$ from that level by day 5 . At $30{ }^{\circ} \mathrm{C}$ growth was observed on all three vegetables. After an initial decline the population on cucumber increased rapidly to $1.6 \log \mathrm{cfu} / \mathrm{cm}^{2}$ above the starting count by $10 \mathrm{~h}$, with a further small increase of $0.2 \log \mathrm{cfu} / \mathrm{cm}^{2}$ at $24 \mathrm{~h}$. On parsley an increase of $0.9 \mathrm{log} \mathrm{cfu} / \mathrm{g}$ was observed by $4 \mathrm{~h}$ and the population then remained stable for the remainder of the experiment. On lettuce a more gradual increase to $1.2 \log \mathrm{cfu} / \mathrm{cm}^{2}$ over the initial count by $10 \mathrm{~h}$ was recorded, followed by a decline back to the starting level by $24 \mathrm{~h}$.

The behaviour of E. coli $\mathrm{O} 157: \mathrm{H7}$ at $10{ }^{\circ} \mathrm{C}$ was not dissimilar to that of $S$. Typhimurium, in that a gradual decline of up to $1.4 \log \mathrm{cfu} / \mathrm{cm}^{2}$ or $/ \mathrm{g}$ was observed on all three vegetables. At $20{ }^{\circ} \mathrm{C}$, growth of up to $0.9 \log$ $\mathrm{cfu} / \mathrm{g}$ was observed on parsley, but population changes on the other vegetables were negligible. At $30{ }^{\circ} \mathrm{C}$ growth was observed on all three vegetables. E. coli $\mathrm{O} 157: \mathrm{H} 7$ on parsley and cucumber followed a similar growth path from $4 \mathrm{~h}$ onwards, reaching around $1.2 \mathrm{log} \mathrm{cfu} / \mathrm{cm}^{2}$ or $/ \mathrm{g}$ above the starting level by $6 \mathrm{~h}$ and remaining at approximately that level for the remainder of the experiment. On lettuce, E. coli 0157:H7 initially followed a similar growth curve up to $6 \mathrm{~h}$, but then declined to around $0.7 \log \mathrm{cfu} / \mathrm{cm}^{2}$ above the starting inocula level for the remainder of the incubation period.

Presumptive E. coli $\mathrm{O} 157: \mathrm{H} 7$ rifampicin variants and Salmonella enterica colonies were not isolated from any of the uninoculated samples. 

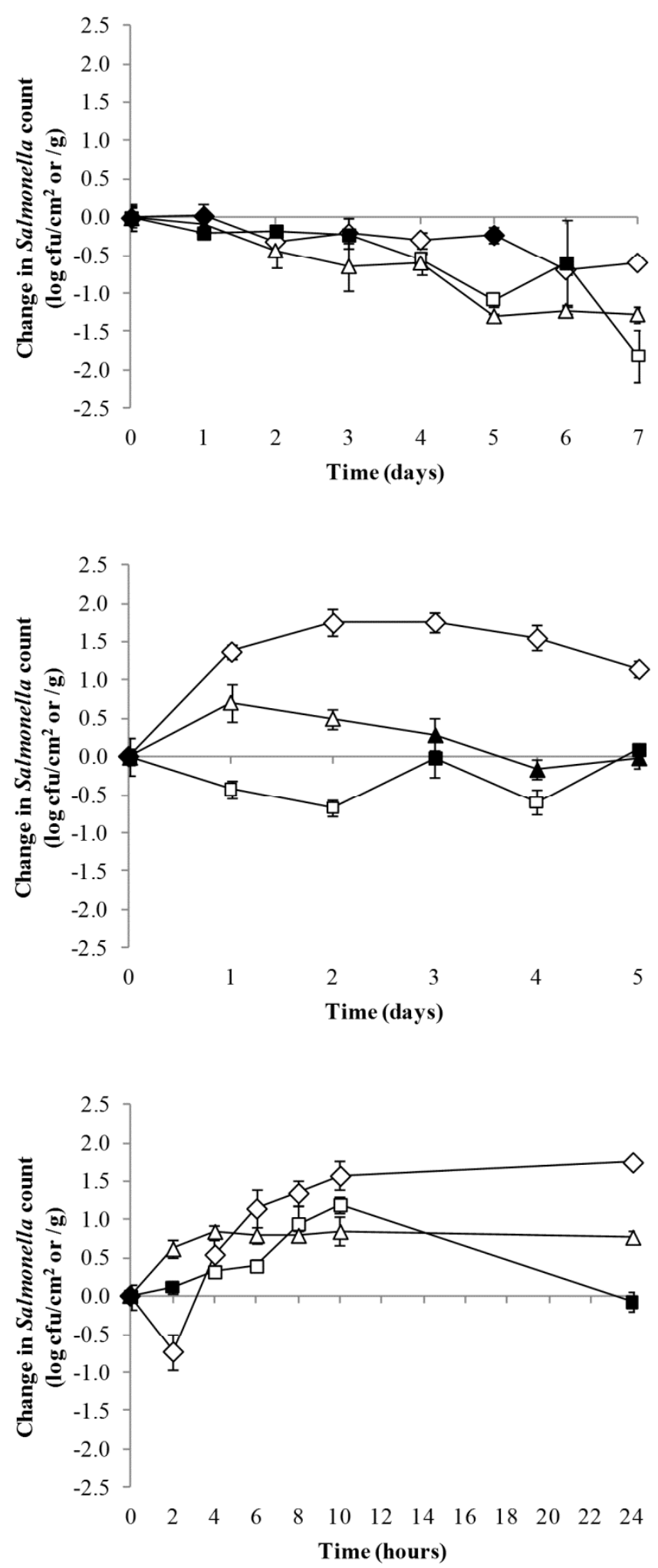

Figure 1. Behaviour of Salmonella Typhimurium on cucumber (rhombi), lettuce (squares) and parsley (triangles) at $10{ }^{\circ} \mathrm{C}$ (top), $20^{\circ} \mathrm{C}$ (middle) and $30^{\circ} \mathrm{C}$ (bottom). Within each series open shapes are significantly $(\mathrm{P}<0.05)$ different to the time 0 value. Mean starting inocula were 2.9-3.3 log cfu/ $/ \mathrm{cm}^{2}$ (cucumber), 3.2-3.5 log cfu/ $/ \mathrm{cm}^{2}$

(lettuce) and 4.3-4.8 log cfu/g (parsley) 

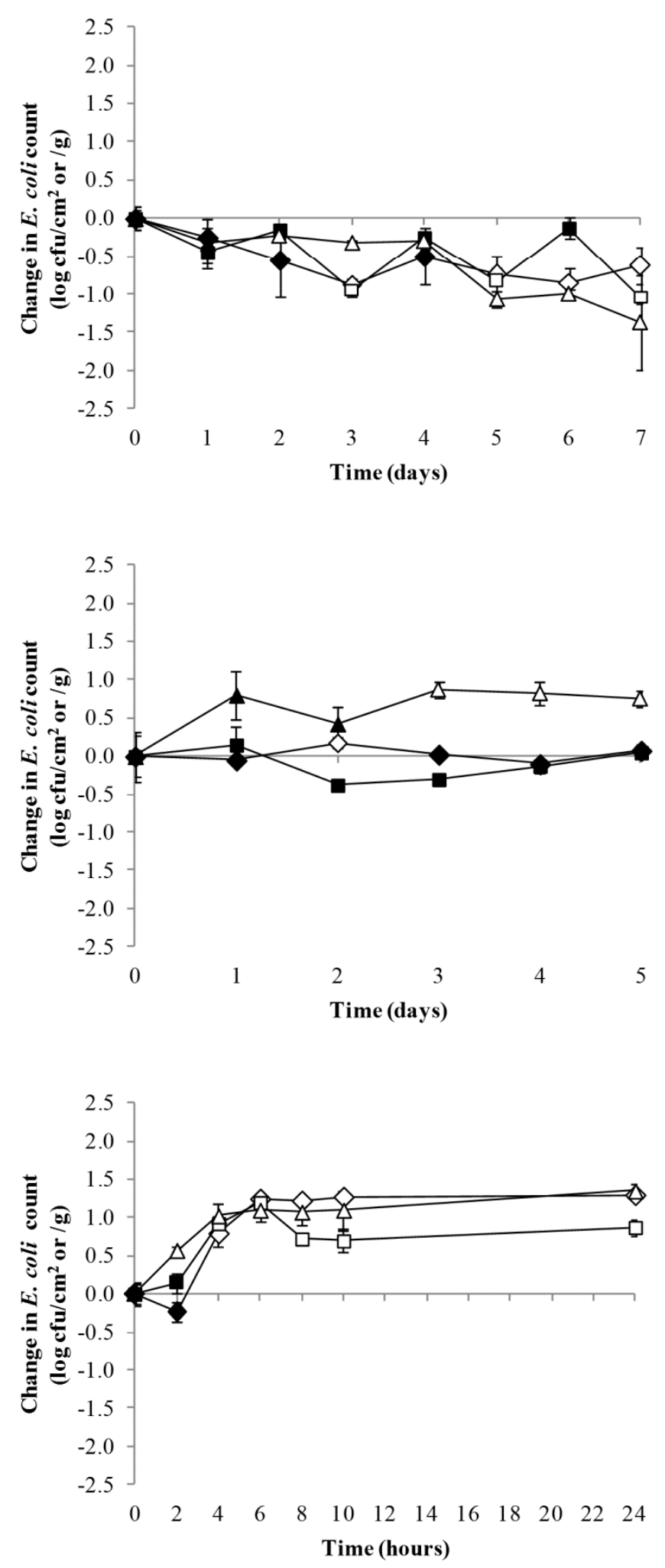

Figure 2. Behaviour of Escherichia coli $\mathrm{O} 157: \mathrm{H} 7$ on cucumber (rhombi), lettuce (squares) and parsley (triangles) at $10{ }^{\circ} \mathrm{C}$ (top), $20^{\circ} \mathrm{C}$ (middle) and $30^{\circ} \mathrm{C}$ (bottom). Within each series open shapes are significantly $(\mathrm{P}<0.05$ ) different to the time 0 value. Mean starting inocula were 3.8-5.0 log cfu/ $/ \mathrm{cm}^{2}$ (cucumber), 3.8-4.1 log cfu/ $/ \mathrm{cm}^{2}$ (lettuce) and 5.2-5.7 log cfu/g (parsley) 


\section{Discussion}

Growth and survival of $E$. coli $\mathrm{O} 157: \mathrm{H} 7$ was not consistently affected by vegetable type, but $S$. Typhimurium grew better on cucumber epidermis than on the two leafy vegetables at $20^{\circ} \mathrm{C}$ and $30{ }^{\circ} \mathrm{C}$ and showed the greatest overall increase in numbers on cucumber of all the organism and vegetable combinations. The reason for this improved growth of $S$. Typhimurium on cucumber and the lack of difference between vegetables in the case of $E$. coli $\mathrm{O} 157$ is not clear, but may be due to differences in nutrient availability on the cucumber that $S$. Typhimurium is able to exploit while $E$. coli $\mathrm{O} 157$ is not.

Lack of growth at $10{ }^{\circ} \mathrm{C}$ shows that this temperature is an effective hurdle even though it is above the recorded minimum growth temperature for both organisms. $S$. Typhimurium has been shown to grow at $6.1{ }^{\circ} \mathrm{C}$ (Matches $\&$ Liston, 1968) although growth is very slow below $15^{\circ} \mathrm{C}$ (Smith, 1985). E. coli $\mathrm{O} 157$ has been demonstrated to grow in minced beef at $6{ }^{\circ} \mathrm{C}$ (Tamplin, Paoli, Marmer, \& Phillips, 2005). However, these minimum temperatures were determined using optimal or near-optimal conditions as far as the other parameters affecting growth are concerned $\left(\mathrm{pH}, \mathrm{A}_{\mathrm{w}}\right.$, nutrients etc.). Sub-optimal conditions can raise the minimum temperature at which the organism can grow (Koutsoumanis, Kendall, \& Sofos, 2004). There may also be inter-strain variation in the minimum temperatures for growth: the cultures used in the present work, although of the same serotypes as those used in the above-quoted publications, may differ slightly in their growth characteristics.

In cases where growth was observed at 20 and $30{ }^{\circ} \mathrm{C}$, the populations of the challenge organisms reached their maximum or near-maximum levels quickly relative to the time-frame of the experiments, i.e. within $6-10 \mathrm{~h}$ at $30{ }^{\circ} \mathrm{C}$ or within 1 day at $20^{\circ} \mathrm{C}$. Lack of significant further growth suggests that the carrying capacity of the vegetable surfaces had been reached within this time, although it is possible that growth was stopped by an unfavorable change in conditions on the vegetable surface caused by water loss, for example. The time-temperature conditions above could readily be encountered during the transport and retail sale of vegetables even if they would normally be kept refrigerated in the home or restaurant. A few hours on a market stall in a hot country or unrefrigerated overnight storage in the home or retailer could allow significant growth of Salmonella enterica or E. coli $\mathrm{O} 157$ if the vegetable had been contaminated during harvest or during subsequent handling. The stacking of vegetables and their packing in crates provides many opportunities for vegetable-to-vegetable contact and therefore cross-contamination should some of the vegetables have been contaminated in the field.

On lettuce, the maximum increase in viable count observed was $1.2 \mathrm{log} \mathrm{cfu} / \mathrm{cm}^{2}$ for both Salmonella and E. coli O157. Several other authors have studied the growth of Gram-negative pathogens on lettuce and observed greater increases in numbers. Koseki and Isobe (2005) recorded an increase in the populations of Salmonella and E. coli $\mathrm{O} 157$ of the order of $2.5 \mathrm{log} \mathrm{cfu} / \mathrm{g}$ at $25{ }^{\circ} \mathrm{C}$, while an increase of Salmonella and E. coli $\mathrm{O} 157$ viable count of up to around $4.0 \mathrm{log} \mathrm{cfu} / \mathrm{g}$ in both cases was observed by Oliveira et al. (2010). Abdul-Raouf, Beuchat and Ammar (1993) observed growth of E. coli O157 of up to $6 \mathrm{log} \mathrm{cfu} / \mathrm{g}$ on lettuce stored at $21{ }^{\circ} \mathrm{C}$. However, there is an important difference between the above works and the present work: all of the above works used shredded lettuce which was inoculated in bulk (i.e. in bags with a known weight of lettuce). The inoculum would therefore be in contact with the cut surfaces from which water and nutrients leak, facilitating growth. In the present work, the inoculated surface was undamaged as far as could be determined by visual inspection and so the plant's natural barriers to water and nutrient loss were intact in the inoculated area.

The dose of $S$. Typhimurium or E. coli $\mathrm{O} 157$ required to cause illness in the consumer varies widely with the food vehicle, the infected individual and the infecting strain, and it is consequently impossible to quantify accurately (Kothary \& Babu, 2001). Data gathered from Salmonella enterica food poisoning outbreaks suggests a minimum infective dose of the order of hundreds of cells, with higher numbers of ingested cells increasing the probability of infection (Blaser \& Newman, 1982). The minimum infective dose of E. coli O157 is lower, of the order of tens of cells or less (Anonymous, 2003). While no level of contamination of a foodstuff with $S$. enterica or E. coli $\mathrm{O} 157$ can be considered safe, the ability of the organisms to grow increases the probability that the consumer will become ill and so is a hazard to food safety. Special care should be taken in storing fresh produce in the appropriate temperatures and washing them prior to consumption, even though that does not necessarily remove all pathogens that might be present (Nastou et al., 2012).

\section{Conclusion}

Growth of Escherichia coli $\mathrm{O} 157: \mathrm{H} 7$ and Salmonella Typhimurium declined slowly on all three vegetables at $10^{\circ} \mathrm{C}$. On parsley and lettuce at $20^{\circ} \mathrm{C} \mathrm{S}$. Typhimurium population returned to roughly the starting count at the end of the experiment whereas it increased in cucumber. Growth was observed on parsley for E. coli $\mathrm{O} 157: \mathrm{H} 7$, but population changes on the other vegetables were negligible at $20^{\circ} \mathrm{C}$. At $30^{\circ} \mathrm{C}$ growth was observed on all three vegetables for both E. coli $\mathrm{O} 157: \mathrm{H} 7$ and $S$. Typhimurium. These findings have implications for 
microbiological safety of fresh vegetables. In conclusion, the microbiological risk presented by fresh vegetables can be increased by storage/handling at temperatures above $10{ }^{\circ} \mathrm{C}$. Growth on undamaged leaf surfaces is reduced compared to that on shredded leaves, an important consideration when comparing data from the literature.

\section{Acknowledgments}

This work was funded internally by the Research Committee of Alexandrian Technological Educational Institute of Thessaloniki. No outside funding was used.

\section{References}

Abdul-Raouf, U. M., Beuchat, L. R., \& Ammar, M. S. (1993). Survival and growth of Escherichia coli O157:H7 on salad vegetables. Applied and Environmental Microbiology, 59, 1999-2006.

Ackers, M. L., Maho, B. E., Leahy, E., Goode, B., Damrow, T., Hayes, P. S., ... \& Slutsker, L. (1998). An outbreak of Escherichia coli O157:H7 infections associated with leaf lettuce consumption. Journal of Infectious Diseases, 177, 1588-1593. http://dx.doi.org/10.1109/iembs.1995.579676

Anonymous. (2003). Opinion of the scientific committee on veterinary measures relating to public health on verotoxigenic E. coli (VTEC) in foodstuffs. European Commission, Health and Consumer Protection Directorate General. Retrieved from http://ec.europa.eu/food/fs/sc/scv/out58_en.pdf

Beuchat, L. R. (2002). Ecological factors influencing survival and growth of human pathogens on raw fruits and vegetables. Microbes and Infection, 4, 413-423. http://dx.doi.org/10.1016/S1286-4579(02)01555-1

Blaser, M. J., \& Newman, L. S. (1982). A review of human salmonellosis I: infective dose. Reviews of Infectious Diseases, 4, 1096-1106. http://dx.doi.org/10.1093/clinids/4.6.1096

Doyle, M. P., \& Erickson, M. C. (2008). Summer meeting 2007 - the problems with fresh produce: an overview. Journal of Applied Microbiology, 105, 317-330. http://dx.doi.org/10.1111/j.1365-2672.2008.03746.x

Elviss, N. C., Little, C. L., Hucklesby, L., Sagoo, S., Surman-Lee, S., De Pinna, E., \& Threlfall, E. J. (2009). Microbiological study of fresh herbs from retail premises uncovers an international outbreak of salmonellosis. International Journal of Food Microbiology, 134, 83-88. http://dx.doi.org/10.1016/j.ijfoodmicro.2009.01.015

Food and Drug Administration. (2013). FDA Investigates Multistate Outbreak of Salmonella Saintpaul linked to cucumbers supplied by Daniel Cardenas Izabal and Miracle Greenhouse. Retrieved from http://www.fda.gov/Food/RecallsOutbreaksEmergencies/Outbreaks/ucm349461.htm

Hilborn, E. D., Mermin, J. H., Mshar, P. A., Hadler, J. L., Voetsch, A., Wojtkunski, C., \& Slutsker, L. (1999). A multistate outbreak of Escherichia coli O157:H7 infections associated with consumption of mesclun lettuce. Archives of Internal Medicine, 159, 1758-1764. http://dx.doi.org/10.1001/archinte.159.15.1758

Islam, M., Doyle, M. P., Phatak, S. C., Millner, P., \& Jiang, X. (2004a). Persistence of enterohemorrhagic Escherichia coli $\mathrm{O} 157: \mathrm{H} 7$ in soil and leaf lettuce and parsley grown in fields treated with contaminated manure composts or irrigation water. Journal of Food Protection, 67, 1365-1370. http://dx.doi.org/10.1016/j.fm.2004.04.007

Islam, M., Morgan, J., Doyle, M. P., Phatak, S. C., Millner, P., \& Jiang, X. (2004b). Persistence of Salmonella enterica serovar Typhimurium on lettuce and parsley and in soils on which they were grown in fields treated with contaminated manure composts or irrigation water. Foodborne Pathogens and Disease, 1, 27-35. http://dx.doi.org/10.1089/153531404772914437

Koseki, S., \& Isobe, S. (2005). Prediction of pathogen growth on iceberg lettuce under real temperature history during distribution from farm to table. International Journal of Food Microbiology, 104, 239-248. http://dx.doi.org/10.1016/j.ijfoodmicro.2005.02.012

Kothary, M. H., \& Babu, U. S. (2001). Infective dose of foodborne pathogens in volunteers: a review. Journal of Food Safety, 21, 49-73. http://dx.doi.org/10.1111/j.1745-4565.2001.tb00307.x

Koutsoumanis, K. P., Kendall, P. A., \& Sofos, J. N. (2004). Modeling the boundaries of growth of Salmonella Typhimurium in broth as a function of temperature, water activity, and pH. Journal of Food Protection, 67, 53-59.

Likotrafiti, E., Smirniotis, P., Nastou, A., \& Rhoades, J. (2013). Effect of relative humidity and storage temperature on the behaviour of Listeria monocytogenes on fresh vegetables. Journal of Food Safety, 33, 
545-551. http://dx.doi.org/10.1111/jfs. 12087

Liu, C., Hofstra, N., \& Franz, E. (2013). Impacts of climate change on the microbial safety of pre-harvest leafy green vegetables as indicated by Escherichia coli $\mathrm{O} 157$ and Salmonella spp. International Journal of Food Microbiology, 163, 119-128. http://dx.doi.org/10.1016/j.ijfoodmicro.2013.02.026

Matches, J. R., \& Liston, J. (1968). Low temperature growth of Salmonella. Journal of Food Science, 33, 641-645. http://dx.doi.org/10.1111/j.1365-2621.1968.tb09092.x

Nastou, A., Rhoades, J., Smirniotis, P., Makri, I., Kontominas, M., \& Likotrafiti, E. (2012). Efficacy of household washing treatments for the control of Listeria monocytogenes on salad vegetables. International Journal of Food Microbiology, 159, 247-253. http://dx.doi.org/10.1016/j.ijfoodmicro.2012.09.003

Oliveira, M., Usall, J., Solsona, C., Alegre, I., Viñas, I., \& Abadias, M. (2010). Effects of packaging type and storage temperature on the growth of foodborne pathogens on shredded 'Romaine' lettuce. Food Microbiology, 27, 375-380. http://dx.doi.org/10.1016/j.fm.2009.11.014

Oliveira, M., Viñas, I., Anguera, M., \& Abadias, M. (2012). Fate of Listeria monocytogenes and Escherichia coli O157:H7 in the presence of natural background microbiota on conventional and organic lettuce. Food Control, 25, 678-683. http://dx.doi.org/10.1016/j.foodcont.2011.12.002

Olsen, S. J., Mackinon, L. C., Goulding, J. S., \& Slutsker, L. (2000). Surveillance for foodborne disease outbreaks-United States, 1993-1997. Morbidity and Mortality Weekly Report, 49, 1-51.

Paull, R. E. (1999). Effect of temperature and relative humidity on fresh commodity quality. Postharvest Biology and Technology, 15, 263-277. http://dx.doi.org/10.1016/S0925-5214(98)00090-8

Sagoo, S. K., Little, C. L., Ward, L., Gillespie, I. A., \& Mitchell, R. T. (2003). Microbiological study of ready-to-eat salad vegetables from retail establishments uncovers a national outbreak of salmonellosis. Journal of Food Protection, 66, 403-409.

Sant'Ana, A. S., Franco, B. D. G. M., \& Schaffner, D. W. (2012). Modeling the growth rate and lag time of different strains of Salmonella enterica and Listeria monocytogenes in ready-to-eat lettuce. Food Microbiology, 30, 267-273. http://dx.doi.org/10.1016/j.fm.2011.11.003

Semenov, A. V., Van Overbeek, L., \& Van Bruggen, A. H. C. (2009). Percolation and survival of Escherichia coli O157:H7 and Salmonella enterica serovar Typhimurium in soil amended with contaminated dairy manure or slurry. Applied and Environmental Microbioliology, 75, 3206-3215. http://dx.doi.org/10.1128/AEM.01791-08

Smith, M. G. (1985). The generation time, lag time, and minimum temperature of growth of coliform organisms on meat, and the implications for codes of practice in abattoirs. The Journal of Hygiene (Lond), 94, 289-300. http://dx.doi.org/10.1017/S0022172400061519

Tamplin, M. L., Paoli, G., Marmer, B. S., \& Phillips, J. (2005). Models of the behaviour of Escherichia coli $\mathrm{O} 157: \mathrm{H} 7$ in raw sterile ground beef stored at 5 to 46 degrees C. International Journal of Food Microbiology, 100, 335-344. http://dx.doi.org/ 10.1016/j.ijfoodmicro.2004.10.029

Tian, J. -Q., Bae, Y. -M., Choi, N. -Y., Kang, D. -H., Heu, S., \& Lee, S. -Y. (2012). Survival and growth of foodborne pathogens in minimally processed vegetables at 4 and $15^{\circ} \mathrm{C}$. Journal of Food Science, 77, 48-50. http://dx.doi.org/10.1111/j.1750-3841.2011.02457.x

\section{Copyrights}

Copyright for this article is retained by the author(s), with first publication rights granted to the journal.

This is an open-access article distributed under the terms and conditions of the Creative Commons Attribution license (http://creativecommons.org/licenses/by/3.0/). 